\title{
Fantasyomslag för alla åldrar
}

\section{Eva Nordlinder}

Det första intryck vi får av en pappersbok utgörs oftast av omslaget. Naturligtvis spelar även andra faktorer in, som var vi får syn på boken, om någon presenterar den muntligt på ett lockande sätt, hur tjock den verkar vara och så vidare. Omslagets utformning har dock stor betydelse för att väcka den blivande läsarens intresse och det signalerar även vilken målgrupp förlaget tänkt sig samt vilken genre boken tillhör. Ett missvisande omslag kan skrämma iväg presumtiva läsare, och ett alltför lockande kanske drar till sig fel målgrupp, som sedan blir besviken när själva läsningen inte lever upp till omslagets löften. "Utformingen av bokomslaget er en retorisk handling som forlaget utförer for å overbivise publikum om at boken er et godt kjöp och vel verd å lese” skriver Hanne Cath. Brkke, som studerat bokomslag ur retorisk synvinkel (Brkke 2010: 6). En vuxen kanske främst noterar författarens namn, bokens titel samt förlagsnamnet och vänder sedan på boken för att läsa baksidestexten. Barn och unga däremot bedömer i högre grad boken direkt efter omslaget bild och layout - och har kanske svårare att ge en bok med "fel” omslag en chans (se Nordlinder 2008).

Omslagslayouten är givetvis en väsentlig del av förlagens arbete och marknadsföring. Ofta avgör formgivare i samarbete med marknadsavdelningen hur omslaget ska utformas och vad som är viktigast att lyfta fram - författarens namn om denna är känd, titeln som presenterar bokens ämne, eventuellt serien en bok kan ingå i samt själva genren. På de stora förlagen har man som författare ibland, men inte alltid, möjlighet att påverka valet av omslagsbild och layout. Vissa förlag använder sig också av fokusgrupper med barn och unga, om dessa är målgruppen - något som fler måhända borde anamma. Formgivaren kan också ha önskemål, som kanske inte stämmer överens med förlagets idéer: ”Jag älskar svartvitt och gråskalan, fast ibland är det svårt att få göra sådana omslag” säger Lotta Kühlhorn, en av Sveriges mest kända omslagsformgivare, i en intervju i Dagens Nyheter (Wallgren 2016).

Fantasy är en genre som skickar tydliga signaler till sina läsare och där det finns en hög grad av konsensus kring symboliken (Guanio-Uluru 2015). En standarduppsättning av motiv används för att snabbt låta konsumenten känna sig trygg med att det är en fantasybok man håller i handen: "For many people fantasy can be identified by its cover art. A dragon or a wizard is usually a clue; but so is a half-naked barbarian (male or female) wielding a sword”. (Mendelsohn \& James 2012: 5)

Fantasy kan betraktas som en allålderskategori som lika gärna läses av vuxna som barn och unga. I denna artikel ska fantasykonventioner i klassisk fantasy studeras, och hur de återanvänds på omslag riktade till yngre läsare.

\section{Paratextens teori}

En teoretisk bakgrund till bokens yttre signaler finner vi i Gerard Genettes bok Paratexts Thresholds of Interpretation (1997). Den franska titeln Seuils (1987) betyder helt enkelt "trösklar" och saknar underrubrik. Varför man i den engelska översättningen valt det mer 
teoretiska begreppet "paratexts" som titel och hänvisat tröskelbegreppet till underrubriken kan vi bara spekulera i, men åtminstone på svenska uppfattas kanske ordet tröskel mer negativt - ett litet hinder, som kan orsaka att man snubblar. Genette laborerar också med begreppet "vestibule" (1997: 2), som på svenska kanske snarast motsvarar "farstu” - alltså ett mellanting mellan inne och ute där man kan fortfarande ändra sig och vända om, men lika gärna välkomnas in.

Allt utom den berättande textmassan kallas paratexter enligt Genette. Paratexten är en övergång, tröskel eller farstu om man så vill, mellan författare, förlag, bok och läsare. Paratexten - och i detta sammanhang särskilt omslaget - kan alltså både underlätta och försvåra för en presumtiv läsare att ta sig an en bok. När omslaget öppnar dörren in i texten skickar det signaler, som den tilltänkta köparen/lånaren/läsaren känner sig bekväm med och som väcker nyfikenhet och positiva känslor. Det krävs inslag både av det välbekanta och trygga, men även en viss del av spänning samt något som väcker nyfikenhet. Det kan ju vara något så enkelt som en ny del i ens favoritserie, som väcker förväntningar och lockar till läsning.

Paratextens funktion är att utgöra det första mötet med boken - vad ser vi? Vilka förväntningar har vi och vilka får vi? Vilken förförståelse har vi? Känner vi till författarens namn, bokserien eller reagerar vi kanske på omslagssymboliken? Blir vi lockade eller bortstötta? Även e-böcker och ljudböcker har paratexter i form av ”omslag” och information. Till och med en muntligt framförd text kan sägas ha en paratext i form av rösten och kanske åsynen av den som läser eller berättar.

Paratext består enligt Genettes teorier av de båda kategorierna peritext och epitext. Peritexten utgörs av inslag som finns i eller på själva bokvolymen, medan epitexten befinner sig utanför den fysiska boken i form av marknadsföring, intervjuer, författarporträtt, leksaker och andra tillbehör, förhandspublicering eller privata brev. I detta sammanhang kommer inte epitexten att behandlas.

"Genette hävdar att det enda vi kan vara riktigt säkra på är att ingen paratext, hur oansenlig den än framstår, finns där av en slump" skriver Anette Årheim, som studerat bl a omslagen till "sanna berättelser" i boken Misery Lit (2012: 33). Detta motsägs delvis av Braekke, som menar att ett författarporträtt kan komma på avvägar, tidsbrist göra att delar måste utgå, designer och redaktör kan bli osams och så vidare, vilket leder till ett visst mått av slumpmässighet även i formgivningen (Brkke 2010: 7).

\section{Omslagets delar}

Formatet på boken spelar självklart roll för hur omslaget kan designas. De allra flesta böcker har numera ett stående rektangulärt format (bilderböcker undantagna). Ett liggande format eller ett mycket smalt stående skickar genast ett budskap om originalitet, liksom ett mycket litet eller mycket stort format.

Omslagsbilden fångar i många fall ögat först. Den kan sträcka sig runt hela boken - framoch baksida samt ryggen. Brkke menar (och här stöder hon sig på medieforskarna Kress och van Leeuwen) att bilden alltid får den omedelbara uppmärksamheten, och att blicken först efter det går till textelementen. I västerlandet läser vi av omslaget från vänster till höger, uppifrån och ner (Brkke 2010: 17). Omslagsbilden kan väljas som en illustration till bokens 
innehåll, eller för att väcka nyfikenhet, eller bara som ett dekorativt element. Den kan också samspela med titel och författarnamn i färg och stil.

Författarnamnet kan naturligtvis på ett sätt anses som den viktigaste informationen - utan författare ingen text. Beroende på författarens status får dock namnet varierande placering på omslaget. Ju mer känd författaren är, desto större, mer lättläst och centralt placerat är namnet enligt den generella regeln (Genette 1997: 39). Författaren behöver inte vara känd just som författare, utan kan vara en idrottspersonlighet, artist, skådespelare, mediakändis eller något annat - om namnet är välkänt förutsätts det bidra till marknadsföringen.

En bild på och presentation av författaren är mycket vanlig när det gäller vuxenlitteratur. Denna information placeras ofta på insidan av skyddsomslaget (även kallat "dust jacket”). De flesta barn- och ungdomsböcker saknar dock skyddsomslag, och information om författarens person framstår inte som så högt prioriterad för barn och unga. Ibland kan även en bild på författaren själv användas som omslagsbild, särskilt på verk som balanserar mellan skönlitteratur och självbiografi.

Titeln är naturligtvis viktig för hur vi uppfattar boken. Ibland är det en beskrivning av innehållet, kanske främst när det gäller fackböcker. Skönlitteratur namnges ofta på ett sätt som ska kittla nyfikenheten. Ibland är titeln central för hur boken ska uppfattas. Ett exempel som Genette nämner är James Joyce Ulysses (1922, på svenska Odysseus 1946) - läsningen av den boken skulle blivit helt annorlunda om den haft en annan titel. I barnlitteraturen är personnamn relativt vanliga i titlarna. Oftast ger det en vink om vem huvudpersonen är, men inte alltid. Ett välkänt exempel är Janne, min vän (1985) av Peter Pohl, där de flesta anser att bokens huvudperson är berättaren Krille istället för Janne (se till exempel Nikolajeva 2004: 94). När det gäller deckargenren är dock inte titeln det viktigaste (tvärtom kan de många gånger vara svåra att komma ihåg eftersom de ofta är så lika varandra), utan författarens namn, förlaget och en eventuell serie - som ofta utgörs av huvudpersonen/detektiven i boken - är viktigare. Hur titeln är designad på omslaget är självklart också av stor betydelse storlek, placering, typsnitt och färg på bokstäverna är faktorer som har betydelse. Rosa, runda bokstäver ger givetvis ett annat intryck än svarta, gotiska. Undertitel förekommer inte så ofta på skönlitterära omslag, men när den finns kan funktionen vara att definiera genren, till exempel "en sann historia”, eller på annat sätt leda in läsarens tankar på ett visst spår i läsningen.

Förlagsnamn och logotyp är kanske viktigast när det gäller så kallad genrelitteratur. En deckarentusiast vet vilka förlag som ger ut brittiska kvalitetsdeckare, vilket ger en trovärdighet och kan väcka läslust även om man aldrig hört författarnamnet förut, och samma gäller för fantasy och science fiction. Allmänt sett har dock klyftan mellan kvalitetsförlag och mer "populära” förlag minskat - för 30 år sedan kunde man vara mer säker på vad man fick i handen bara utifrån förlagsnamnet. Men fortfarande har de stora etablerade förlagen en viss tyngd och gott renommé - förlaget blir en garant för författaren som i sin tur blir en garant för texten, skriver Genette (1997: 46). En seriebeteckning kan vara mycket viktig för den läsare som följer en serie.

På vissa böcker anges en genrebeteckning redan på omslaget (till exempel roman eller thriller). Detta tycks dock betydligt vanligare när det gäller vuxenlitteratur. Barn- och ungdomsböcker har sedan länge släppt den typen av bestämningar som var vanliga för 100 år 
sedan, "Berättelse för unga flickor”, ”Äventyrsberättelse för pojkar” och så vidare där inte bara genre, utan även målgrupp angavs redan på omslaget.

Citat från tidigare recensioner eller rekommendationer brukar oftast förekomma på pocketutgåvan eller nya upplagor, av förklarliga skäl. Det har dock blivit allt vanligare att man trycker en rekommendation, gärna från en mer känd författarkollega, redan på första upplagans omslag.

Baksidestexten är naturligtvis utomordentligt viktig för den blivande läsaren, och är en genre i sig, som inte kan utredas här. Oftast är det förlaget som står för baksidestexten, och det är tyvärr inte alltid som den gör innehållet rättvisa. Men för de flesta av oss är det förmodligen baksidestexten som avgör om vi tar med oss en bok hem för att läsa den. Det initiala intresset, som gör att vi greppar boken och vänder på den, måste dock väckas av komponenter på framsidan.

Streckkoden fyllde tidigare ingen funktion för köparen, utan var endast en uppgörelse mellan förlag och handel för att underlätta hanteringen, medan man numera kan scanna den med hjälp av en app och få mer information om boken i handen. Även ISBN-numret som identifierar boken återfinns på streckkodsetiketten. Priset återfinns oftast på omslaget, men är i många fall ditsatt av bokhandlaren. I den presumtiva köparens ögon spelar avsändaren dock mindre roll, priset bidrar ändå starkt till hur motiverad man blir att köpa boken!

Ryggtext består oftast av författarnamn, titeln och en förlagslogotyp (eller namnet), men detta kan variera, delvis beroende på bokens tjocklek och höjd. När boken har bundits in i ett biblioteksband ersätts den ursprungliga designen av ett standardiserat tryck på enfärgad bakgrund. Detta kan drabba bilder som sveper runt hela omslaget, alltså även ryggen.

Även bokens fysiska utformning, det vill säga papperskvalitet, tjocklek, typ av band (pocket, inbunden, kartonnage, skinnband, infärgning av kanterna, sidenband som bokmärke med mera) ger signaler till läsaren/köparen. Att en bok kommer som pocket tyder oftast på att den sålt bra i sin ursprungliga, inbundna utgåva. Det i sig ger en positiv signal, att boken gillats av andra. På pocketutgåvorna är det också i det närmaste obligatoriskt med citat från uppskattande recensioner.

\section{Fantasyomslagens huvudingredienser}

Bokomslagen kan ses som "genrernas uniformer", skriver Anette Årheim apropå "sanna berättelser ur livet” (2012: 92). Detta stämmer även bra på fantasygenren, som ofta uppträder i en ganska likartad "uniform”. Därför passar fantasyböcker bra som exempel på omslagsdesign och hur man utnyttjar olika element.

I det följande ska vi studera några av fantasyns standardverk, och hur man valt att formge omslagen till dessa böcker. Böckerna är endast exempel som visar på typiska ingredienser och stilar, och många andra titlar och motiv kunde tagits upp. Flera titlar finns dessutom utgivna med olika omslag, vilket också hade varit intressant att studera.

\section{Kampen}

På omslaget till Elizabeth Moons The Deed of Paksenarrion (1992) etableras ett grundmotiv i fantasyn, konflikten eller kampen. Hjälten som kommer ridande på en häst är en kvinna, vilket avslöjas av den tajta brynjan, men hon har ändå en full rustning på sig, vilket inte är 
alla kvinnliga fantasygestalter förunnat - ofta återges de halvklädda och med starka sexistiska undertoner (se t ex Roberts \& MacCallum-Stewart, 2016). Motståndarna representeras av två vargliknande varelser. Hästens muskler och svärdet som är lyft till anfall signalerar kraft och rörelse - svärdet och vargarna rör sig mot varandra. Den välvda titeln understryker rörelsen och förhåller sig också till skogshorisonten i bakgrunden. Författarnamnet - väl bekant för fantasyläsare - är något mindre än titeln men i gengäld mer lättläst. Högst upp meddelas: "Complete at last - the finest trilogy of the decade”. Förlaget vänder sig här till dem som hört tals om serien och vill läsa alla delarna i ett svep.

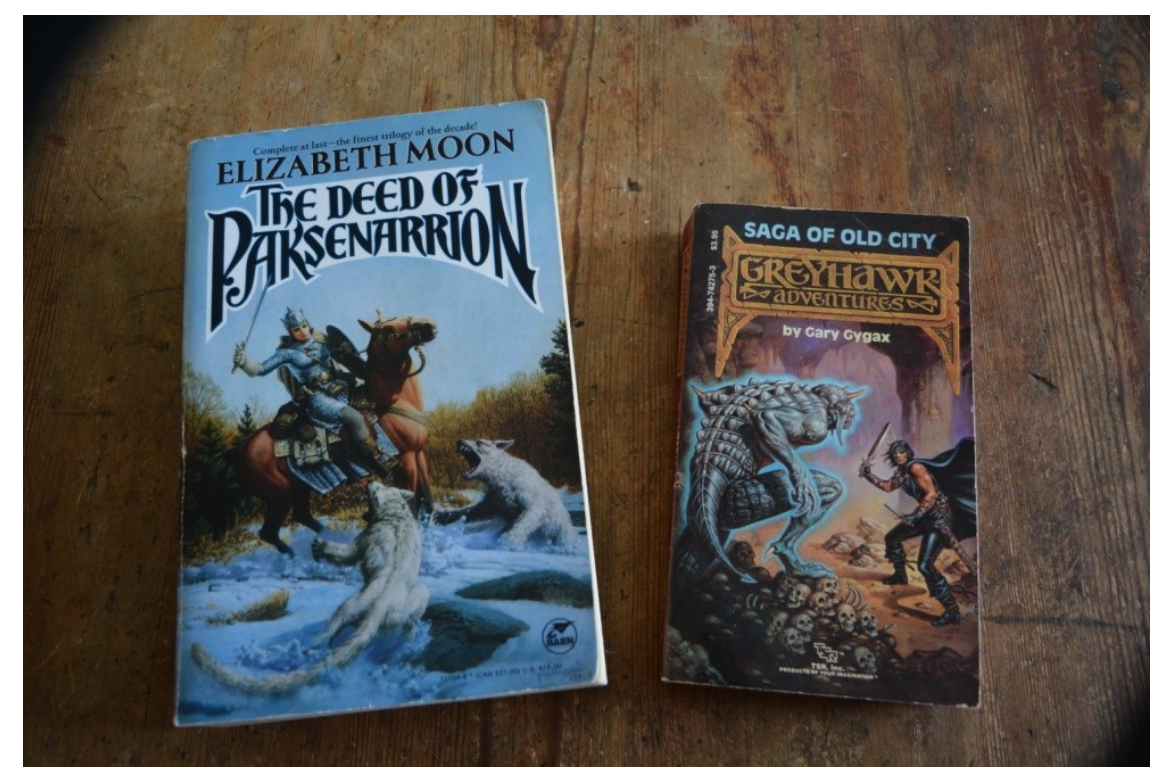

Bild 1

Gary Gygax Saga of old city. Greyhawk Adventures (1985) är måhända främst intressant tack vare författaren (Dungeons \& Dragons skapare), men omslaget förtjänar ändå att diskuteras. Författarnamnet är visserligen litet men sticker ut rejält tack vare att det har ett avvikande typsnitt och dessutom lyser vitt. På detta omslag står kampen mellan en manlig hjälte (faktiskt mer lättklädd än kvinnan i föregående exempel) och en demon med drakliknande framtoning, som befinner sig närmast åskådaren, vilket gör att hjälten framstår som allt mer hotad. Hjälten har både ett svärd och en dolk samt en fladdrande mantel. Dödskallarna som demonen tycks stå stadigt på symboliserar ondskan. Liksom på många fantasyomslag är det svårt att avgöra vilket som är serien och vilket som är den enskilda volymens titel. "Greyhawk Adventures" är inramat i keltisk stil, något som också är mycket vanligt förekommande. Logotypen med serienamnet knyter också an till en av förlagets TCR:s Dungeons \& Dragons-världar.

\section{Det metafysiska uppdraget}

Den andra kategorin av typiska fantasyomslag kan kategoriseras som det metafysiska uppdraget, vilket Robin Hobbs Vargbroder (2003), i original Royal Assassin (1997), är ett exempel på. Hjälten på bilden är lugn, säker på sin storslagna uppgift och blickar uppåt och framåt mot seger (eller har han redan uppnått den?). Även här finns en varg, men i denna situation som hjälpare och följeslagare. Vargen och hjälten lyfter ansiktet respektive nosen i samma vinkel, mot det himmelska ljuset. Månen och solen (solnedgång eller soluppgång?) 
lyser upp. Hjälten håller fortfarande i svärdet men är inte längre beredd till strid. Bröstet är blottat, han har alltså ingenting att frukta (längre?) - han har kastat sin rustning. I bakgrunden skymtar ett gotiskt slott, något som återkommer på flertalet fantasyomslag. Den knotiga rotvälta de befinner sig på kan vara ett dekorativt inslag i likhet med keltiska slingor.

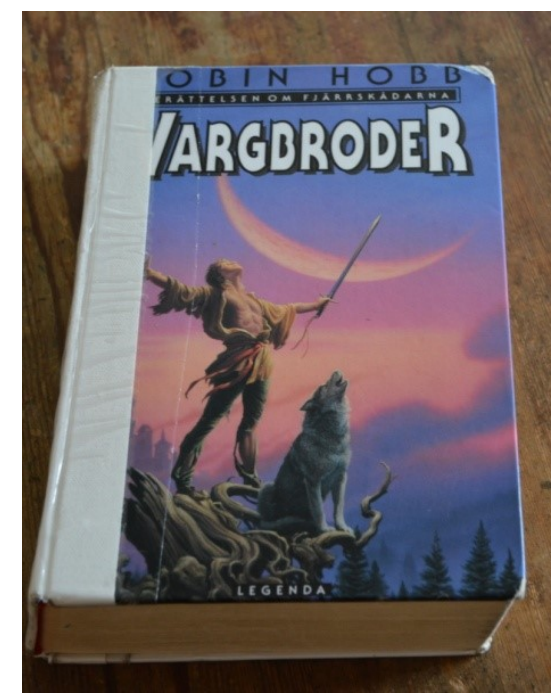

Bild 2

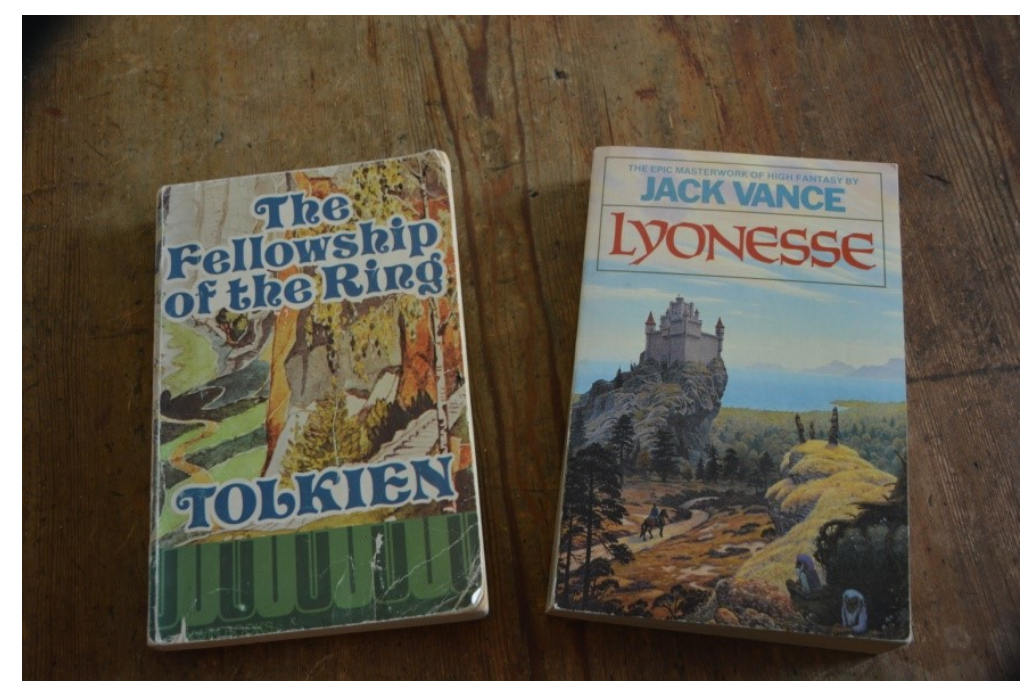

Bild 3

\section{Det mytiska landskapet}

En tredje grundkategori av fantasyomslag kan beskrivas som det mytiska landskapet. Omslaget till Jack Vance Lyonesse (1983) visar de olika landskapselementen - skog, klippor, hav - och det ofta förekommande slottet i huvudrollen, människor och andra varelser ingår bara som en liten del i det stora hela. Här dras blicken till slottet på klippan och leds dit av den vindlande vägen. Även ryttaren är på väg till slottet, men vi vet inte i vilket ärende. De små vättarna i förgrunden betraktar ryttaren, men deras avsikter är oklara. Även de anspelar på keltisk/irisk mytologi, liksom kraftstenarna uppe på klippan. Typsnittet på titeln ger också keltiska associationer. Havet ger en känsla av oändlighet, medan de ytterst detaljerat avbildade växterna markerar nuet. Boken får av förlaget beteckningen ”The epic masterwork of high fantasy”, vilket kanske med ännu större rätt kunde använts på omslaget till Tolkiens 
The Fellowship of the Ring, som här exemplifieras av en utgåva från 1974, med Tolkiens egen illustration som omslagsbild, året efter hans död. Sambandet mellan författare, text och bild understryks av att titeln och författarnamnet har samma typsnitt - han är boken, boken är han. Förnamnen finns inte med, ens som initialer. Här får läsaren ett landskap som ingång till handlingen - inga varelser syns till. Vi har två vägar att välja mellan, den vindlande vägen till vänster och en trappa till höger. Vägvalet är viktigt - vilken väg är den rätta? Den sirliga björken antyder ett nordiskt landskap snarare än ett keltiskt.

\section{Ungdomsfantasyns omslag}

Omslagen är som sagt det främsta medlet att nå särskilt yngre läsare - ändå tycks det många gånger vara svårt för förlagen att hitta rätt ton när målgruppen är barn och unga. ${ }^{1}$ Vissa förlag använder sig som sagt av fokusgrupper, medan andra verkar lyckligt omedvetna om vad som kan tänkas attrahera en ung läsare. Nedan studeras några barn- och ungdomsböcker i fantasygenren för att se hur grunddragen som beskrivits ovan används och eventuellt förändras.

\section{Draken}

Draken är ett vanligt förekommande element och motiv i fantasy för barn och unga, som på Martin Bergströms omslag till A J Lakes Drakens bok (2007) återfinns både i titeln och naturligt nog på bilden. Både draken och titeln är blanka och nästan självlysande, och titeln är tryckt i silver, något som nästan blivit obligatoriskt i svensk ungdomsfantasy. Omslaget är inte alls lika detaljrikt som de tidigare behandlade böckerna, men drakens svans bildar i sig den vindlande vägen, och kan också påminna om en slottsmur eller dylikt. Ljuset i fjärran kan vara en soluppgång eller solnedgång. Författarnamnet är här litet och mörkt och placerat på samma rad som seriens namn, vilket gör det mindre betydelsefullt. Det är också oklart om författaren är man eller kvinna. På det svenska förlagets webbplats kan man dock läsa att "hon har tidigare arbetat som lärare” (metoden att ersätta namnet med initialer för att göra det könsneutralt har ju även använts av J K Rowling).

\footnotetext{
${ }^{1}$ Omslagen till förklädnadsromaner för ungdomar har studerats av Mia Österlund i artikeln ”I textens tambur”. Även hon menar att: ”Det finns mycket att önska när det gäller omslagen till ungdomsromaner.” (s. 32)
} 


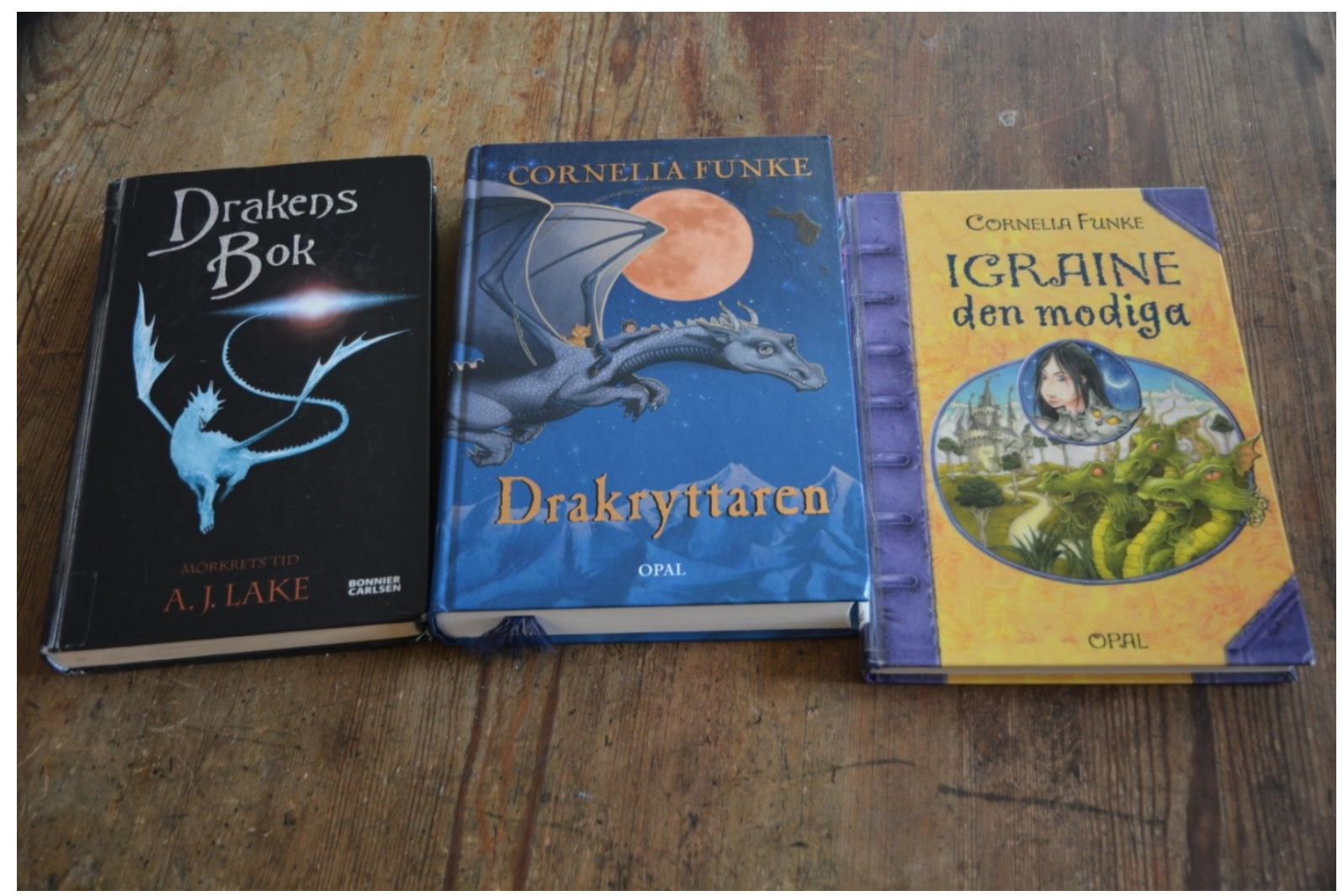

Bild 4

På omslaget till Cornelia Funkes Drakryttaren (2005) hittar vi föga förvånande ytterligare en drake, men nu med passagerare. Här märker man tydligt att den tänkta målgruppen är yngre, både genom drakens finurligt godmodiga ansiktsuttryck, den pyjamasklädde pojken som påminner om en seriefigur och den käcka katten som tittar fram. För övrigt återfinner vi både klassiska bergstoppar och en måne, här i form av en fullmåne. Författarnamnet - ett av de främsta inom barn- och ungdomsfantasyn - matchar väl titeln i storlek och färg, och den oranga färgen tas också upp av månen.

Omslaget till Cornelia Funkes Igraine den modiga (2007), även det en bok riktad till målgruppen 9-12 år, saknar inga fantasyingredienser. Här finns drakar i pluralis, den vindlande vägen, det mystiska slottet och de tydligt avbildade små träden. Dimhöljda berg i fjärran och en månskära bakom huvudpersonen fullbordar symboliken. Omslaget kan dock uppfattas som barnsligt och plottrigt, och dessutom ser hjältinnan mycket ung ut. Drakarna liknar måhända mer Bolibompadrakar än värdiga motståndare. Slottet är inte skrämmande på det rätta gotiska sättet, och hjältinnan ser lite fånig ut, vilket katten tycks hålla med om. Detta omslag avvisades kategoriskt av de detagande barnen i projektet Barns smak, där elever i åldrarna 9-12 röstade fram sina omslagsfavoriter (se Nordlinder 2008). Det välkända författarnamnet hjälpte alltså inte. Ramen som ger illusion av ett gammalt bokband tilltalade inte heller - man ville inte ha "gamla" historier.

\section{Vargar}

Melissa Marrs I ljuset av din skugga (2011) är ett exempel på vad man lite slarvigt skulle kunna kalla för "tjejfantasy”, eller "paranormal” (som utspelar sig huvudsakligen i vår realistiska värld, men med magiska och romantiska inslag) - en subgenre som ökat på senare 
år. På detta omslag finns delar av fantasysymboliken kvar, som vargar och slingor, men hela tilltalet har blivit mer personligt. Det mänskliga ansiktet är i centrum, även om det är lite suddigt och distanserat, med en huvudperson som inte möter betraktarens blick. Det är svårt att veta om hon är hjältinna eller offer. Vargarna som tycks tatuerade på hennes arm är en del av henne själv men ändå hotfulla, och här anas den obligatoriska konflikten eller kampen. Färgskalan spelar på traditionella "flickfärger" som lila och rosa. Det finns också slingor runt namnet, som dock mer liknar blomstergirlanger än keltiska slingor.

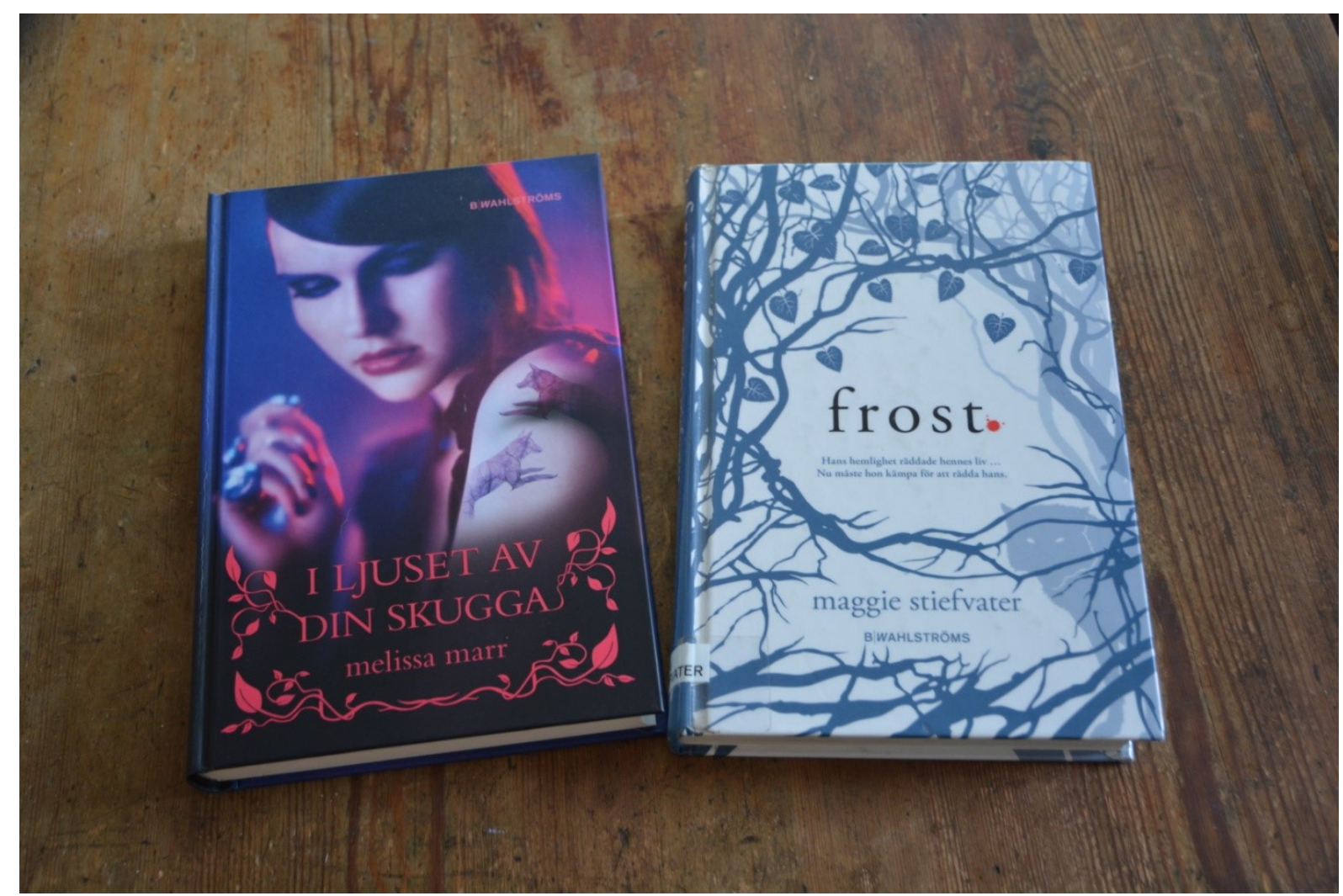

Bild 5

I Maggie Stiefvaters Frost (2010) möter vi några collegeungdomar som förvandlas till vargar, men i övrigt kämpar med samma känslor och problem som andra. Omslaget visar bara en vargsiluett som antyder handlingen, i övrigt är det täckt av diskret blågrå slingor och lite taggiga buskar och grenar. Såväl titeln som författarnamnet är skrivet enbart med gemener, vilket ser modernt ut, och omslaget är tämligen monokront. En blodröd fläck efter ordet frost är den enda färgklicken som bryter av. Boken presenteras istället med två rader text: "Hans hemlighet räddade hennes liv... nu måste hon kämpa för att rädda hans”. Här leds vi in på tanken att romantik kan spela en roll i handlingen.

Middagsmörker (2016) av Charlotte Cederlund utspelar sig i en samisk by, dit huvudpersonen flyttar, och upptäcker att hennes plats i den samiska föreställningsvärlden är mycket viktigare än hon kunnat tro. Märkligt nog återfinns ingenting av samiska symboler eller färger på omslaget, som visar en varg i närbild transparent över ett snöigt skogslandskap återgivet i mörkt grått. Över himlen drar blodröda skyar, vilket ger ett oroväckande intryck. Det röda återkommer på några av titelns bokstäver (Mid). 


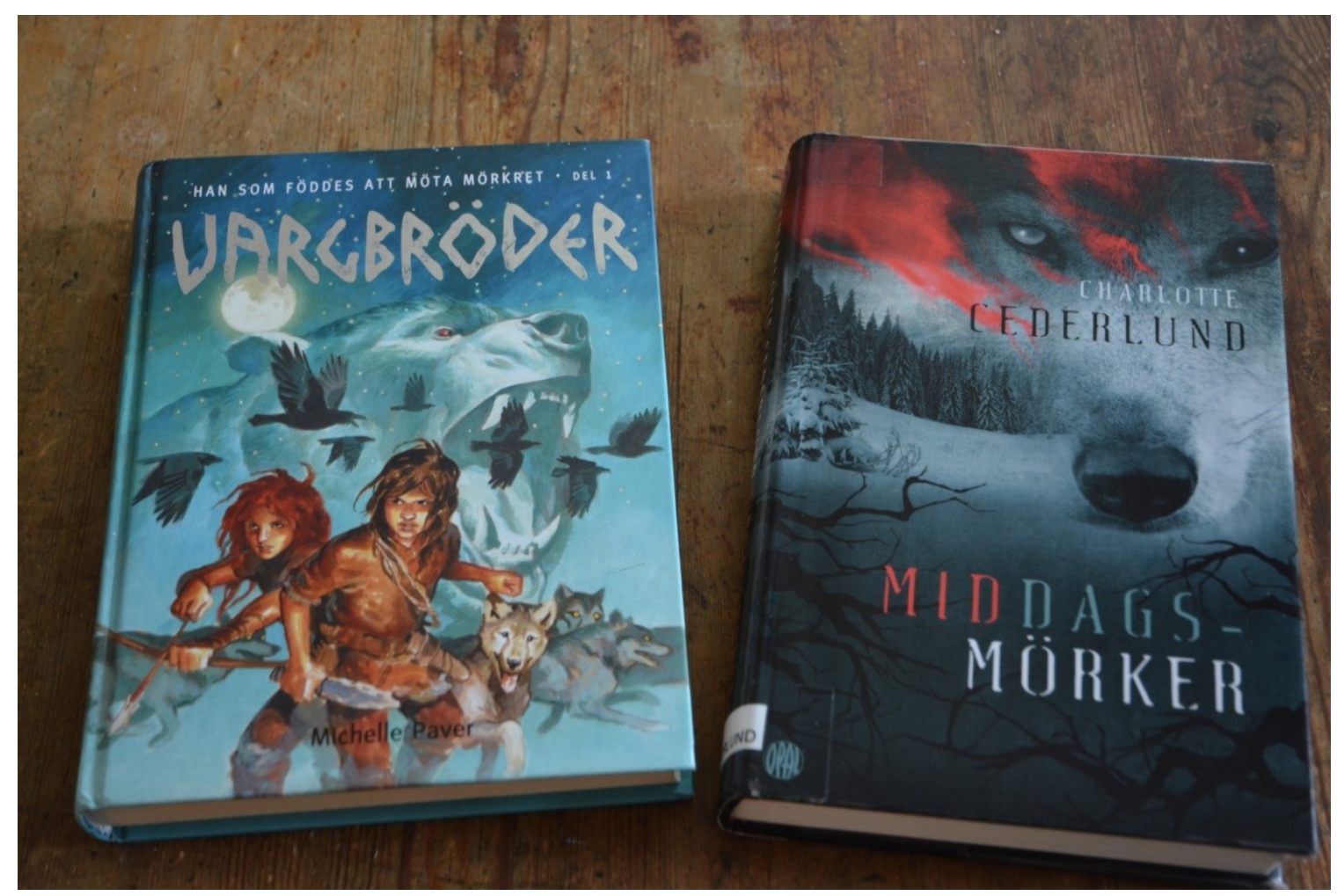

Bild 6

Vargbröder (2005-2010) av Michelle Paver var under flera år en av de mest populära barn/ungdomsserierna (se t ex Bokjuryn 2006-2010). Serien är en blandning av fantasy och historisk skildring av stenåldern, men själva berättelsen i del I: Han som föddes att möta mörkret (2005) innehåller många klassiska fantasyinslag, som ett övermänskligt uppdrag, en demonbjörn och ett djur (en varg) som hjälpare. Huvudpersonen Torak möter både en flicka, Renn, som blir hans följeslagare och en vargunge, Ulv, vars språk han förstår utan att veta varför. Omslaget visar alla de viktiga huvudpersonerna - Torak, Renn och Ulv är avporträtterade i färg i fonden av omslaget. Det är beredda på kamp med vapen i högsta hugg. Bakom dem springer en vargflock - den familj som Ulv förlorat - och överst, men transparent, tronar en grym björn (som vid läsningen visar sig vara en demon). En klunga flygande korpar fullbordar bilden. VARGBRÖDER är skrivet i kraftiga ljusa bokstäver, såväl författarnamnet som deltiteln är betydligt mindre och mörkare (så till den grad att katalogisatören som lagt in boken i nationalbibliografin Libris missuppfattat vad som är serietitel och vad som är boktitel). Man förstår att detta är början på en serie, och att det är den som är viktig. En senare upplaga, Månpocket från 2006, har helt avskaffat de mänskliga huvudpersonerna och har betydligt färre omslagselement. Här dominerar vargen helt, författarnamnet är större och endast en korp seglar ovanför texten. Bokens titel syns inte utan endast ordet Vargbröder i ett kraftigt vitt typsnitt. En förklaring kan vara att Månpockets böcker vänder sig till alla åldrar och att man velat minska ner på de barntillvända inslagen. Att Harry Potter-böckerna på engelska gavs ut med olika omslag för barn respektive vuxna är välkänt. 


\section{Fantasy för nybörjarläsarna}

Att etablera huvudpersonen eller huvudpersonerna redan på omslaget är vanligt när det gäller fantasy för barn, som ovan i fallet Vargbröder. Vi ser också en ökande trend att ha flera huvudpersoner, gärna en av vartdera könet, för att tilltala så många läsare som möjligt (se Svenska barnboksinstitutets Bokprovning, www.sbi.kb.se).

Fantasyvågen har på senare år gått allt längre ner i åldrarna. Niklas Krogs första bok om Tanarog Yxkämpen (2007) blev den absoluta favoriten bland barnen i klass 3 i projektet Barns smak (Nordlinder 2008). Detta omslag av Nils-Petter Ekwall är fullproppat av tydliga fantasy-associationer. Vi känner igen den lilla (keltiska) dvärgen - även namnet Tanarog har keltiska associationer - de röda flätorna, yxan, draken vars nos sticker fram och den detaljerade grönskan. Trädet är en levande varelse (med inspiration från Tolkiens vandrande enter), liksom det svarta monstret som dvärgen kämpar mot. Den lilla etiketten "Läsa själv" bryter fiktionen men detta tycks inte ha stört de unga läsarna. Författarnamnet är välkänt för vuxna, men är inte den viktigaste komponenten för barn i nioårsåldern. Författare och illustratör tillmäts samma vikt och står på samma rad.

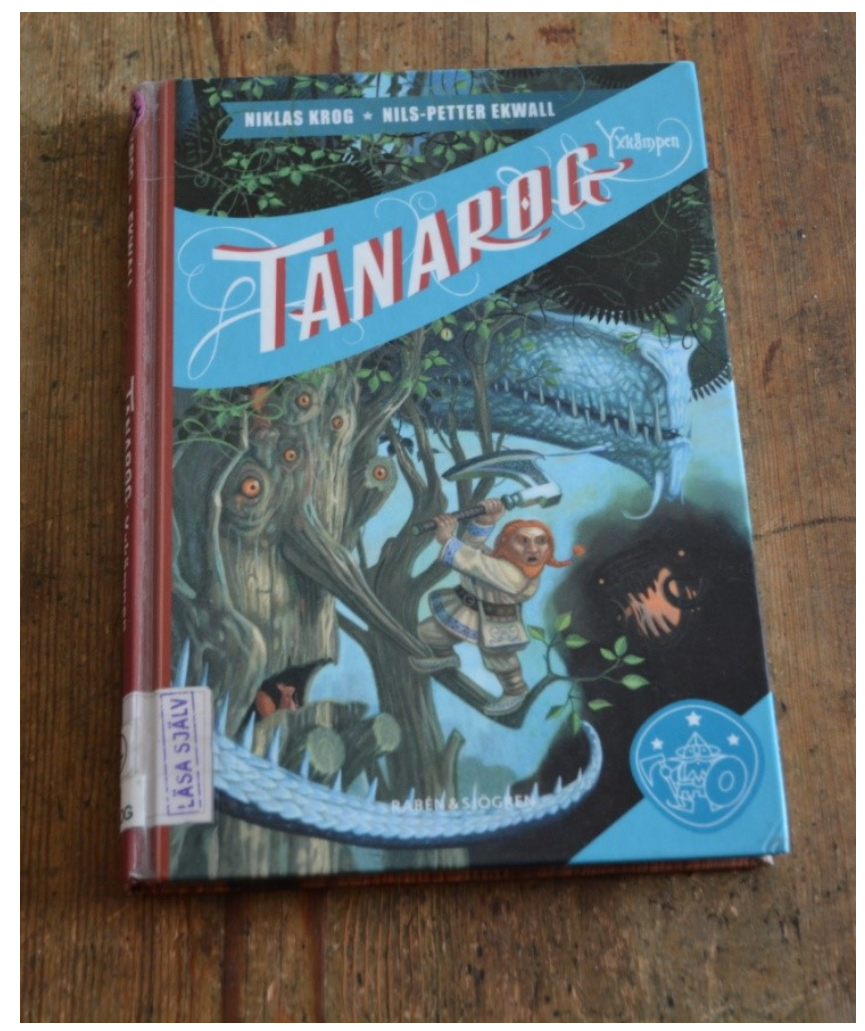

Bild 7

Eleverna i projektet Barns smak visade stor medvetenhet kring genrekonventioner, delvis i text men framförallt när det gällde bild. De identifierade omedelbart de centrala fantasyinslagen på omslaget till Krogs bok, trots att de bara var nio-tio år. En tydlig hjälte, keltiska symboler och en skrämmande motståndare var tacksamma element.

Sammanfattningsvis tycks omslagsbilden och dess genremarkörer av större betydelse för barn än övriga element i paratexten - för en vuxen presumtiv läsare spelar författarnamnet, förlaget, baksidestexten och rekommendationer från tidigare läsare sannolikt större roll än själva bilden. Många av de element som etablerats som klassiska fantasymarkörer på 
bokomslag för vuxna (även om fantasy som sagt är allålderslitteratur) återfinns i lite förenklad form på de omslag som riktar sig främst till yngre läsare. Bilderna är ofta mindre detaljerade, drakarna är mer stiliserade eller humoristiskt tecknade. Naturinslagen med sirliga träd och skrämmande berg saknas, åtminstone på de flesta av de studerade omslagen (ett undantag är Middagsmörker där den täta skogen utgör en olycksbådande fond). Huvudpersonerna står också mer i centrum, vilket kanske är ett sätt att göra omslagen mer lockande för unga läsare.

\section{Referenser}

Bokjuryn, www.bokjuryn.se [20160920]

Brkke, Hanne Cath. (2010), Omslagets retorikk. Hvordan skjønnlittercere debutanter konstitueres som forfattere på bokomslag. Oslo: univ. https://www.duo.uio.no/bitstream/handle/10852/26421/Brxkke_Master.pdf?sequence=1 \&isAlowed=y [20160940]

Cederlund, Charlotte (2016), Middagsmörker. Bromma: Opal. Omslag: Anna Henriksson.

Funke, Cornelia (2005), Drakryttaren. Bromma: Opal. Omslagsbild: Don Seemiller.

Funke, Cornelia (2007), Igraine den modiga. Bromma: Opal. Omslagsbild: Nick Price.

Genette, Gérard (1997), Paratexts: Thresholds of Interpretation. Cambridge: Cambridge University Press.

Guanio-Uluru, Lykke (2015), Ethics and Form in Fantasy Literature: Tolkien, Rowling and Meyer. Houndmills, Basingstoke, Hampshire: Palgrave Macmillan.

Gygax, Gary (1985), Saga of old city. Greyhawk Adventures. Lake Geneva: TSR. Omslagsbild: Clyde Caldwell.

Hobb, Robin (2003), Vargbroder. Stockholm: Legenda (orig Royal Assassin, 1997, Bantam Books). Omslagsbild: Michael Whelan.

Krog, Niklas (2007), Tanarog Yxkämpen. Stockholm: Raben \& Sjögren. Omslagsbild: NilsPetter Ekwall.

Lake, A J (2007), Drakens bok. Stockholm: Bonnier Carlsen. Omslagsbild: Martin Bergström.

Marr, Melissa (2011), I ljuset av din skugga. Stockholm: B Wahlström. Omslagsbild: Mark Tucker.

Moon, Elizabeth (1992), The Deed of Paksenarrion. Riverdale: BAEN Fantasy. Omslagsbild: Keith Parkinson.

Nikolajeva, Maria (2004), Barnbokens byggklossar. 2., [rev. och utök.] uppl. Lund: Studentlitteratur.

Nordlinder, Eva (2008), Barns smak - att välja sin läsning. Paper presenterat vid konferensen Mötesplats Borås 15-16 oktober 2008 (http://bada.hb.se)

Paver, Michelle (2005), Vargbröder I: Han som föddes att möta mörkret. Sundbyberg: Semic. Omslagsbild: Alvaro Tapia.

Roberts, Jude \& MacCallum-Stewart, Esther, red. (2016), Gender and Sexuality in Contemporary Popular Fantasy: Beyond Boy wizards and Kick-ass Chicks. Abingdon/Oxon:

Routledge.

Stiefvater, Maggie (2010), Frost. Stockholm: B. Wahlström. Omslagsbild: Christopher Stengel.

Tolkien, J R R (1974), The Fellowship of the Ring. London: Unwin Books. Omslagsbild: J R R Tolkien.

Wallgren, Måns (2016) “Jag vill forma världen som jag vill - intervju med Lotta Kühlhorn”, i 
Dagens Nyheter, http://www.dn.se/bostad/jag-vill-forma-varlden-som-jag-vill/ [201609-15]

Vance, Jack (1983), Lyonesse. London: Granada Publishing. Omslagsbild: Mick van Houten. Österlund, Mia (2001) "I textens tambur: en studie av omslagen till förklädnadsromaner”, i Horisont 2001 (48:2), s. 30-39

\section{Bildförteckning}

Samtliga bilder är tagna av författaren. 